\title{
Phytoplankton and nutrient dynamics in two ponds of the Esmoriz wastewater treatment plant (Northern Portugal).
}

\author{
Pereira, E. ${ }^{(1)(2)}$, Anne, I. ${ }^{(1)}$, Fidalgo, M. L. ${ }^{(1)(2)}$ and Vasconcelos, V. ${ }^{(1)(2)}$ \\ (1)Dep. de Zoologia e Antropologia, Faculdade de Ciências da Universidade do Porto, Praça Gomes Teixeira, \\ 4099-002 Porto, Portugal \\ ${ }^{(2)}$ CIIMAR- Centro de Investigação Marinha e Ambiental Rua do Campo Alegre, nº 823,4150-180Porto, Portugal
}

\begin{abstract}
Phytoplankton dynamics in two ponds of the Esmoriz wastewater treatment plant (Northern Portugal), were studied between December 1998 and July 1999. Ponds were characterized by a wide range of water temperatures (i.e. between 9.1 and 25.3 ${ }^{\circ} \mathrm{C}$ ), and dissolved oxygen concentrations (i.e. $0.9-10.8 \mathrm{mg} \mathrm{l}^{-1}$ in the facultative pond, and $2.8-18.2 \mathrm{mg} \mathrm{l}^{-1}$ in the maturation one). The maximum chlorophyll $a$ concentration was reached in July in the facultative pond (i.e. $2054.6 \mathrm{mg} \mathrm{m}^{-3}$ ) and in February in the maturation pond (i.e. $2042.6 \mathrm{mg} \mathrm{m}^{-3}$ ). Mean chlorophyll $a$ concentrations varied between $694.1 \mathrm{mg} \mathrm{m}^{-3}$ in the facultative pond and $942.1 \mathrm{mg} \mathrm{m}^{-3}$ in the maturation pond. Nutrient concentrations were $1.6 \mathrm{mgl}^{-1} \mathrm{NH}_{4}^{+}-\mathrm{N}, 0.1 \mathrm{mgl}^{-1} \mathrm{NO}_{2}-$ $\mathrm{N}, 10.2 \mathrm{mgl} l^{\prime} \mathrm{NO}_{3}-\mathrm{N}$ and $1.6 \mathrm{mgl}^{-1} \mathrm{PO}_{4}{ }^{3}-\mathrm{P}$. Chlorophytes and euglenophytes dominated the phytoplankton in the facultative pond; the first group represented almost $85 \%$ of total phytoplankton density in January, May and June, whereas euglenophytes reached $96 \%$ of total phytoplankton density in April. The genera Oocystis and Pandorina were dominant within the chlorophytes, while the genus Euglena was dominant within euglenophytes. Cyanobacteria in the maturation pond represented more than $95 \%$ of total phytoplankton density in April, May and July. Dominant cyanobacteria were Planktothrix mougeotii (April and May), Microcystis aeruginosa and Pseudoanabaena mucicola (July). In the maturation pond, euglenophytes were less than $6 \%$ of total phytoplankton abundance, except in March, when Euglena accounted for $67 \%$ of total phytoplankton density. These densities indicate that the wastewater treatment plant (WWTP) may be an optimal habitat for cyanobacteria, and consequently, a possible source of cyanobacterial toxins.
\end{abstract}

Key words: phytoplankton, cyanobacteria, nutrients, waste water treatment plant

\section{RESUMEN}

Desde Diciembre de 1998 a Julio de 1999 se ha estudiado la dinamica del fitoplancton en dos lagunas de la planta de tratamiento de aguas residuales de Esmoriz. Las lagunas se caracterizaronpor un amplio rango de temperaturas (p.e. entre 9.1 y $25.3{ }^{\circ} \mathrm{C}$ ), y concentraciones de oxigeno disuelto (p.e. 0.9- $10.8 \mathrm{mg} \mathrm{l} \mathrm{l}^{-1}$ en la lagunafacultativa, y $2.8-18.2 \mathrm{mg} \mathrm{l}^{-1}$ en la de maduración)- La concentracidn maxima de clorofila a se alcanzó en Julio en la lagunafacultativa $\left(2054.6 \mathrm{mg} \mathrm{m}^{-3}\right)$ y en

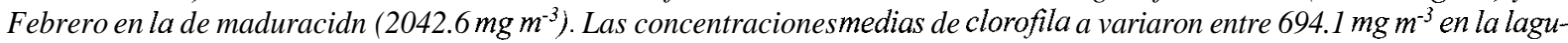
nafacultativa y $942.1 \mathrm{mg} \mathrm{m}^{-3}$ en la de maduracidn. Las concentracionesde nutrientesfueron $1.6 \mathrm{mg} \mathrm{l-1} \mathrm{NH}_{4}-\mathrm{N}_{1} 0.1 \mathrm{mg} \mathrm{l}^{-1}, \mathrm{NO}_{2}$ $\mathrm{N}, 10.2 \mathrm{mg} \mathrm{l}^{-1}, \mathrm{NO}_{3}-\mathrm{Ny}$ y $1.6 \mathrm{mg} \mathrm{l}^{-1} \mathrm{PO}_{4}^{3}$-P. Las cloroficeas y las euglenoficeas dominaron elfitoplancton en la laguna facultativa; el primer grupo representa casi el 85\% de la densidad total delfitoplancton en Enero, Mayo y Junio, mientras que los euglenófitos alcanzaron el $96 \%$ de la densidad del fitoplancton en Abril. Los géneros Oocystisy Pandorinafueron dominantes entre las cloroficeas, mientras que el género Euglena fue dominantes entre las euglenófitas. Las cianobactkrias en Abril, Mayo y Julio representaron más del 95\% de la densidad delfitoplancton en la laguna de maduracidn. Entre las cianoficeas dominantes estaban Planktothrix mougeotii (Abrily Mayo), Microcystis aeruginosa y Pseudobaena mucicola (Julio. En la laguna de maduracidn los euglenófitos alcanzaron densidades menores del $6 \%$ deljtoplancton. Estas densidades indican que la planta de tratamiento de aguas residuales (WWTP) pueden ser un hábitat optimo para las cianobacterias, y consecuentemente, unaposiblefuente de toxinas cianobacterianas.

Palabras clave: fitoplancton, cianobacteria, nutrientes, planta de tratamiento de aguas residuales

Limnetica 20(2): 245-254 (2001)

(C) Asociación Española de Limnologia, Madrid. Spain. ISSN: 0213-8409 


\section{INTRODUCTION}

Lagooning is one of the most common wastewater treatment systems in Portugal (Mendes et al., 1995; Oliveira, 1995). The mutualistic relationship existing between bacteria and the dominant algal community in stabilization ponds of wastewater treatment plants and the dominance of the algal community, promotes the removal of nutrients, organic matter and pathogenic organisms (Troussellier et al., 1986; Curtis \& Mara, 1994; Nurdogan \& Oswald, 1995).

Microalgae play multiple and complex roles in the wastewater treatment. Microalgae release molecular oxygen during photosynthesis, which in conjunction with oxygen at the air-water interface, promotes the aerobic conditions necessary for organic matter degradation by the aerobic bacteria. Also, small algae predominant in WWTP stabilization lagoons transform and accumulate organic matter degraded by the aerobic bacteria (Rodrigues \& Santana, 1993).

The phytoplankton community is often dominated by cyanobacteria in eutrophic ecosystems.
At high densities, cyanobacteria may produce toxins, endangering public health (Vasconcelos \& Araújo, 1994). Common algae in wastewater stabilization ponds belong to Chlorophyceae, Euglenophyceae, Bacillariophyceae and Cyanophyceae (Silva, 1998). Cyanobacteria have been reported to dominate in some WWTP (e.g. in Morocco; Oudra, 1990). Among them, Phormidium is a typical genus in wastewater treatments (Canizares-Villanueva et al., 1994). Silva (1998) recorded the presence of the cyanobacterium Planktothrix sp. in the Parada WWTP (Portugal), although chlorophytes were dominant.

Few studies are available examining the relationship between phytoplankton and nutrient concentration changes in wastewater treatment plants in the Iberian Peninsula and elsewhere (Oudra, 1990). The present paper contributes results of an investigation on the dynamics of the phytoplankton community in a WWTP in Portugal, and their relationship to the main algal nutrients (i.e. phosphorus and nitrogen).

Table 1. Analyses of physical and chemical variables in samples taken from the Esmoriz wastewater treatment plant (WWTP), Northern Portugal. Análisis de las variables fisicas y químicas en las muestras tomadas de la planta de tratamiento de aguas residuales de Esmoriz. (WWTP)

\begin{tabular}{l|l|l}
\hline \multicolumn{1}{c|}{ PARAMETER } & \multicolumn{1}{c|}{ METHOD OF ANALYSES } & \multicolumn{1}{c}{ REFERENCE } \\
\hline Water temperature / Dissolved oxygen & in situ, using a multiparameter device & \\
$\mathrm{pH}$ & in situ, using a multiparameter device & \\
Nitrates & Spectrophotometry & $\begin{array}{l}\text { StricKland \& Parsons } \\
\text { (1972) }\end{array}$ \\
Nitrites & Spectrophotometry & $\begin{array}{l}\text { StricKland \& Parsons } \\
\text { (1972) }\end{array}$ \\
Ammonia & KOROLEFF (1970) \\
Soluble Reactive phosphorus & Spectrophotometry & GOLTERMAN et al. (1978) \\
Photosynthetic pigments & Spectrophotometry & Spectrophotometry with \\
& acidification (HCl IN) & NP 4327 -1996 \\
\hline
\end{tabular}




\section{MATERIAL AND METHODS}

The WWTP at Esmoriz is situated in the North of Portugal (40" 56' $\mathrm{N}$ and $8^{\prime \prime} 38^{\prime} \mathrm{W}$ ), practically at sea level, and covers a total area of 12 ha. It is a system of two sets of ponds, each set being independent and composed by three ponds in series (anaerobic, facultative and maturation). The final effluent is discharged into the river Lambo $(3.5 \mathrm{~m}$ wide, 0.3 to $0.6 \mathrm{~m}$ deep, and annual mean flow of $0.3 \mathrm{~m}^{3} \mathrm{~s}^{-1}$ ). Sampling was monthly between December 1998 and July 1999 in the facultative and maturation ponds. In the maturation pond, samples were taken from the banks and at the outlet. All samples were stored in plastic bottles and immediately preserved with Lugol's solution, for later identification and counting of phytoplankton species. Samples for physical and chemical analyses were kept refrigerated until they were analysed in the laboratory, within 24 hours of collection. Analyses and methods used are described in table 1.

Identification and quantification of phytoplanktonic forms

Different algal species and groups were identified and counted under an inverted microscope $(400 \mathrm{x}$ magnification) using with Utermohl sedimentation chambers of 5 and $25 \mathrm{ml}$. Transects of each sample were counted to an error of less than $20 \%$ (Lund et al., 1958). Results are expressed in cells per millilitre.

\section{Toxin analyses and quantification}

The toxicity of Planktothrix mougeotii was measured with a mouse bioassay. Male Charles River mice (I: Gulbenkian Ciencia, Lisboa; weighing 20$25 \mathrm{~g}$ ) were used. Freeze-dried cyanobacteria were suspended in $0.9 \% \mathrm{NaCl}$ solution. A maximum dose of $1500 \mathrm{mg} \mathrm{Kg}^{-1}$ was used. Survival time and symptoms after ingestion of this solution by mice, were observed during a 48-hour period and postmortem. Toxicity of the water in the different ponds was estimated with an ELISA test specific for microcystins (Envirogard).

\section{Statistical analyses}

Oxygen concentrations, algae-related and chlorophyll $a$ were log-transformed to stabilize variances, before analysis of correlations. Pearson Product-Moment Correlation coefficients were considered as significant at a $\mathrm{p}=0.05$.
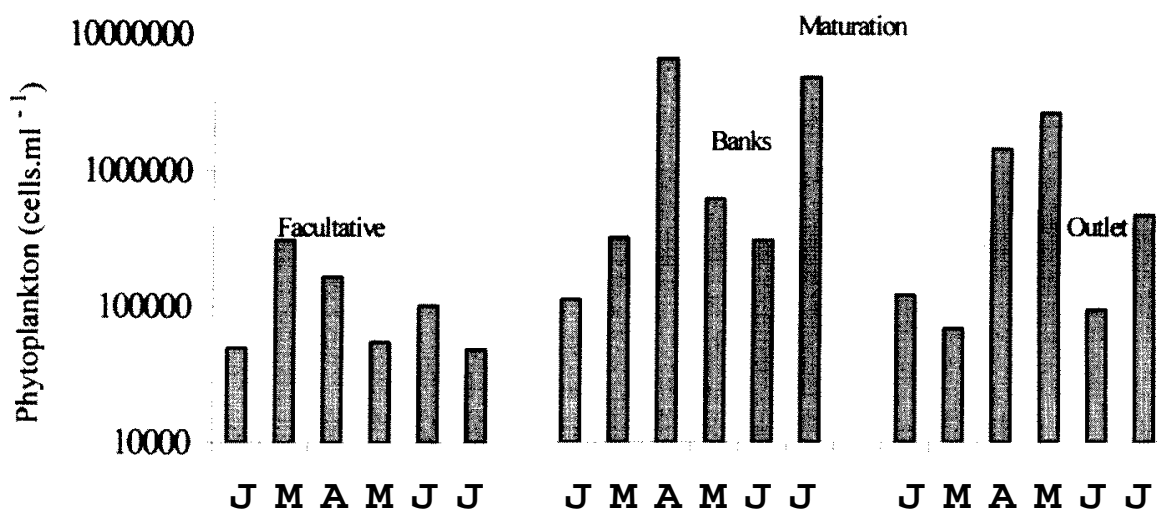

1999

Figure 1. Changes in total phytoplankton abundance in the facultative and maturation (banks and outlet) ponds of Esmoriz WWTP. Cambios en la abundancia total del fitoplancton en la laguna de maduracion de la EDAR de Esmoriz. 


\section{RESULTS}

\section{Phytoplankton dynamics in the facultative} pond

Chlorophytes and euglenophytes were the dominant algal group throughout the sampling period in the facultative pond (Fig. 2A). Chlorophytes represented $80-85 \%$ of total phytoplankton abundance in January, March, May and June, while euglenophytes dominated (i.e. $60-96 \%$ of total phytoplankton abundance) in April and July. The genera Oocystis and Pandorina were dominant among the chlorophytes, and Euglena within euglenophytes.
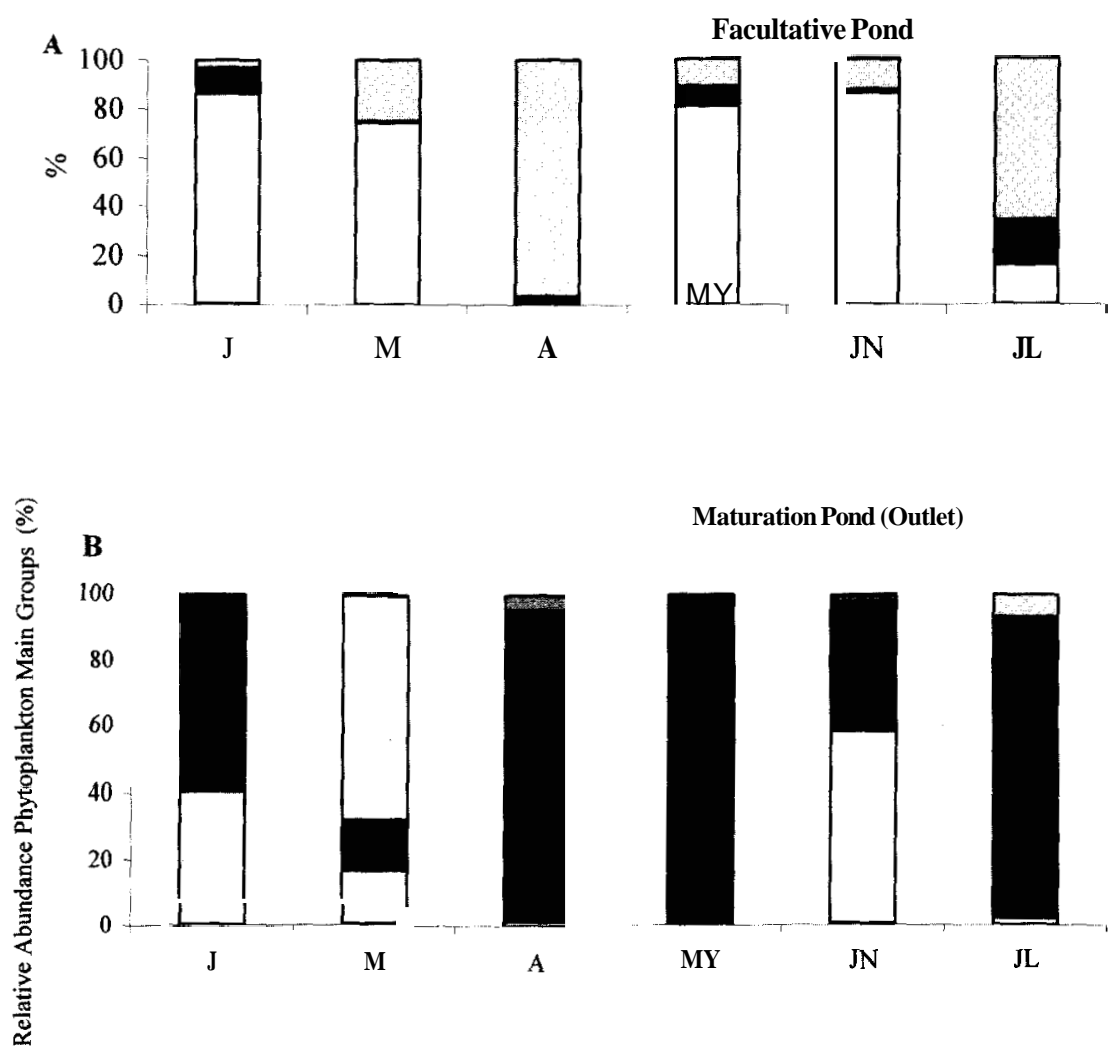

Maturation Pond (Outlet)
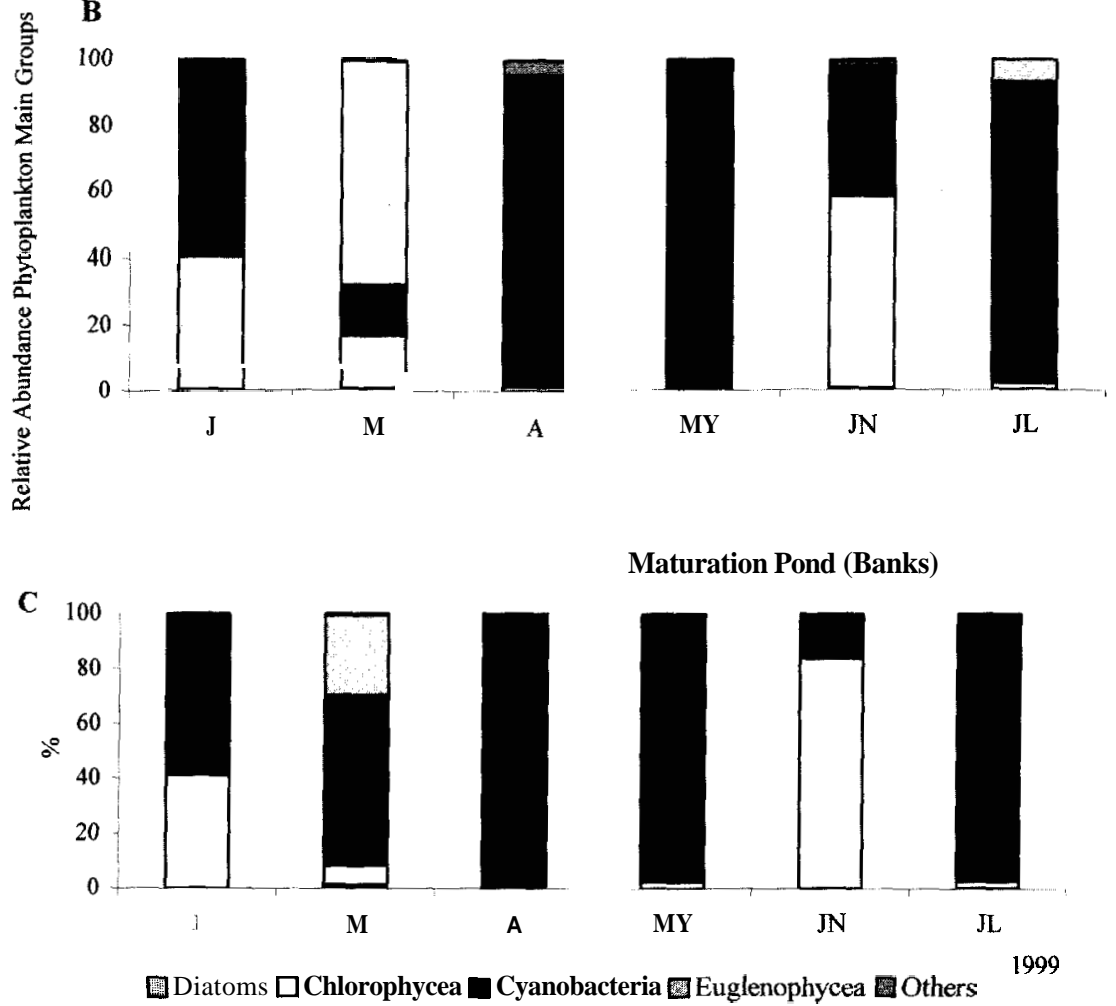

Figure 2. Changes in the relative abundance of phytoplankton main groups in $\mathbf{A}$, the facultative pond and B, the maturation pond at the outlet and $\mathrm{C}$, the maturation pond near the banks Cumbios en la abundancia relativa de los principales grupos del fitoplancton en $A$, la laguna facultativay $B$, la laguna de maduración a la salida y C. la laguna de maduración cerca de las entradas 

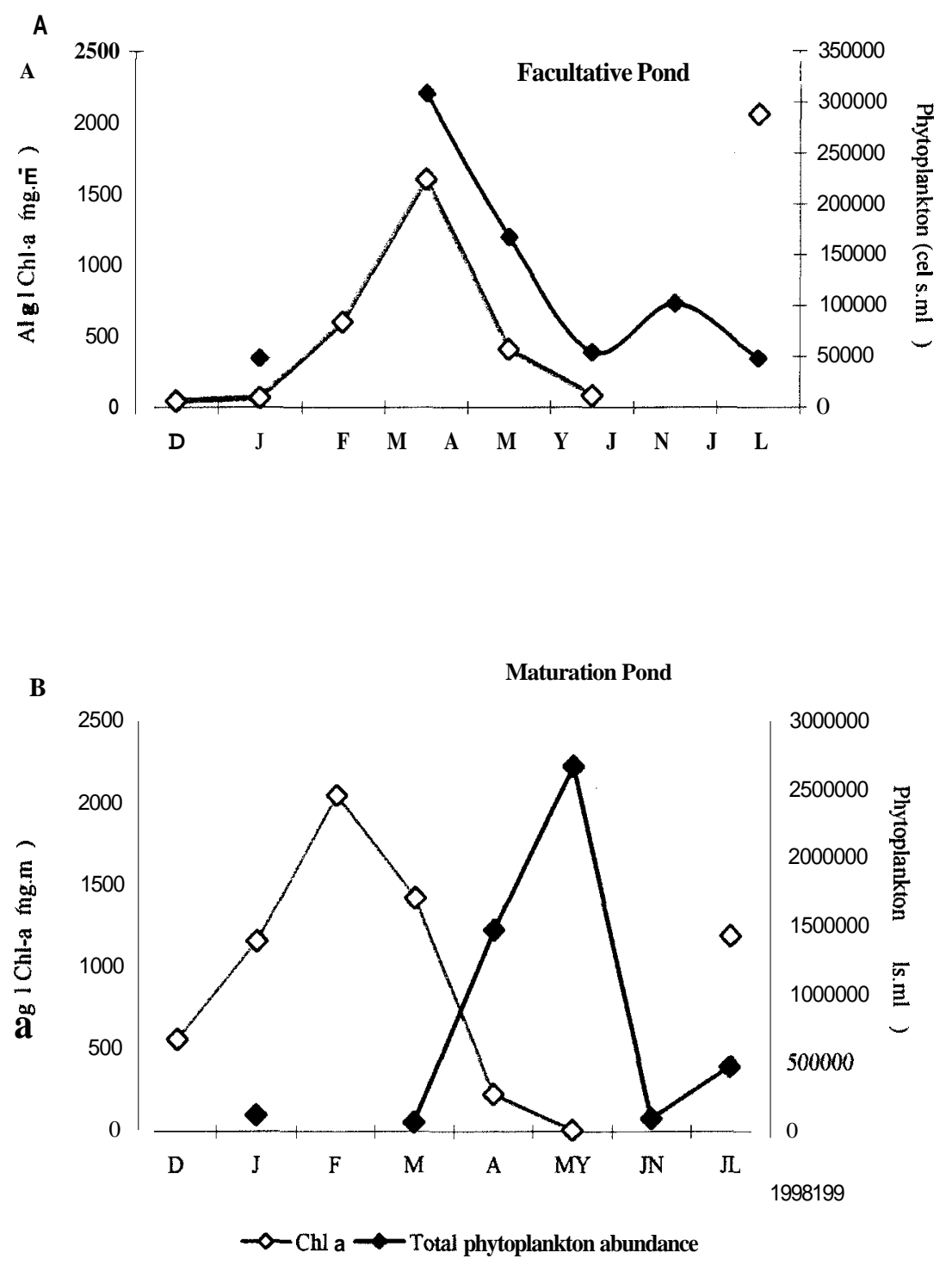

Figure 3. Changes in phytoplankton abundance and chlorophyll a concentrations in $\mathbf{A}$,- the facultative pond and B, in the maturation pond, at the outlet. Cambios en la abundáncia del fitoplancton y en las concentraciones de clorofila a en A.- la laguna facultativa y B, en la laguna de maduracion a la salida.

\section{Phytoplankton dynamics in the maturation pond}

In the maturation pond, the highest abundances were found, at the banks in April and July. Maximum algae abundance was attained in April (banks, $6.7-10^{6}$ cells $\mathrm{ml}^{-1}$ ) and in May (outlet,
$2.7-10^{6}$ cells $\left.\mathrm{ml}^{-1}\right)$. In the facultative pond, the maximum algal density was $0.3-10^{6}$ cells $\mathrm{ml}^{-1}$, attained in March. Cyanobacteria were present in all samples (Figs. 2B \& 2C), and represented over $95 \%$ of total phytoplankton abundance in April, May and July. Planktothrix mougeotii (April and May), Microcystis aeruginosa and 
Table 2. Pearson Product-Moment Correlation coefficients between the analysed physical and chemical variables and the different algal groups in the facultative and maturation ponds of the Esmoriz (WWTP). Coeficientes de correlacidn producto-momento de Pearson entre las variables fisicas y quimicas analizadas y los diferentes grupos de algas en las lagunas facultativa y de muduracidn de Esmoriz (WWTP).

\begin{tabular}{|c|c|c|c|c|}
\hline Variables & $\begin{array}{c}\text { Facultative } \\
\text { pond } \\
\text { r }\end{array}$ & $\mathbf{P}$ & $\begin{array}{c}\text { Maturation } \\
\text { pond } \\
\mathbf{r}\end{array}$ & $\mathbf{P}$ \\
\hline $\begin{array}{l}\text { Chl/ } \\
\text { Diatoms }\end{array}$ & 0.30 & ns & 0.58 & ns \\
\hline $\begin{array}{l}\text { ChV/ } \\
\text { Chlorophytes }\end{array}$ & 0.19 & ns & 0.76 & $\mathrm{~ns}$ \\
\hline $\begin{array}{l}\text { Chl/ } \\
\text { Cyanobacteria }\end{array}$ & -0.96 & 0.04 & -0.74 & ns \\
\hline $\begin{array}{l}\text { Chl/ } \\
\text { Euglenophytes }\end{array}$ & 0.85 & $\mathrm{~ns}$ & 0.23 & $\mathrm{~ns}$ \\
\hline $\begin{array}{l}\text { Oxygenl } \\
\text { Diatoms }\end{array}$ & 0,48 & ns & 0.19 & ns \\
\hline $\begin{array}{l}\text { Oxygenl } \\
\text { Chlorophytes }\end{array}$ & -0.41 & ns & 0.21 & $\mathrm{~ns}$ \\
\hline $\begin{array}{l}\text { Oxygenl } \\
\text { Cyanobacteria }\end{array}$ & 0.08 & ns & -0.05 & $\mathrm{~ns}$ \\
\hline $\begin{array}{l}\text { Oxygen1 } \\
\text { Euglenophytes }\end{array}$ & 0.44 & ns & 0.57 & $\mathrm{~ns}$ \\
\hline $\begin{array}{l}\mathrm{pH} / \\
\text { Diatoms }\end{array}$ & 0.09 & ns & -0.86 & 0.03 \\
\hline $\begin{array}{l}\mathrm{pH} / \\
\text { Chlorophytes }\end{array}$ & -0.80 & ns & -0.40 & $\mathrm{~ns}$ \\
\hline $\begin{array}{l}\mathrm{pH} / \\
\text { Cyanobacteria }\end{array}$ & 0.33 & ns & 0.71 & $\mathrm{~ns}$ \\
\hline $\begin{array}{l}\text { pH/ } \\
\text { Euglenophytes }\end{array}$ & 0.49 & ns & 0.54 & $\mathrm{~ns}$ \\
\hline
\end{tabular}

ns: not significant

\begin{tabular}{l|r|r|r}
\hline \multicolumn{1}{c|}{ Variable } & \multicolumn{1}{c|}{ Ammonia } & \multicolumn{1}{c|}{ Nitrates } & \multicolumn{1}{c}{ SRP* } \\
\hline DIATOMS & $0.27(\mathrm{~ns})$ & $0.72(\mathrm{~ns})$ & $-0.44(\mathrm{~ns})$ \\
Chlorophytes & $0.21(\mathrm{~ns})$ & $-0.06(\mathrm{~ns})$ & $0.57(\mathrm{~ns})$ \\
Cyanobacteria & $-0,58(\mathrm{~ns})$ & $\mathbf{0 . 1 3}(\mathrm{ns})$ & $0.12(\mathrm{~ns})$ \\
Euglenophytes & $-0,78(\mathrm{~ns})$ & $\mathbf{0 . 1 0}(\mathrm{ns})$ & $-0.77(\mathrm{~ns})$ \\
\hline
\end{tabular}

Pseudanabaena mucicola (July) were dominant species. Chlorophytes were the main algal group in June (60-80 \%) and in January (41\%). Oocystis sp. in June and Sphaerolopsis sp. in January were the main chlorophyte species during these periods. Euglenophytes represented less than $6 \%$ of total phytoplankton abundance, except March (67 \%), when Euglena sp. was the dominant species.

In the facultative pond there was a good relationship between chlorophyll $a$ concentration and phytoplankton density, while this was not true for the maturation pond (Figs. 3 \& 4). Highest oxygen concentrations were found in April in both sampling locations. Pearson Product-Moment Correlation coefficients are shown in Tables $2 \& 3$.

Changes in ammonia, nitrate and soluble reactive phosphorus concentrations against chlorophyll $a$ in the maturation pond are shown in Figure 5.

\section{DISCUSSION}

The two ponds are clearly different, in both phytoplankton abundance and algal species composition and proportions of each algal group. These differences are related to nutrient concentrations (nitrogen and phosphorus), hydrodynamics of the ponds, dissolved oxygen concentrations and organic matter in both ponds.

\section{Facultative pond}

In the facultative pond, phytoplankton was mainly composed by chlorophytes and euglenophytes (Figs. $2 \& 3$ ), in agreement with data reported by Oliveira (1995). In March, the maximum algae abundance coincided with the maximum concentration of chlorophyll $a$. Chlorophyll $a$ concentration reached $2054.6 \mathrm{mg} \mathrm{m}^{-3}$ in July. Dissolved oxygen concentrations ranged between 0.9 and $10.8 \mathrm{mgl}^{-1}$ (Fig. 3A \& 4A).

Cyanobacteria apparently made up less of the chlorophyll $a$ than diatoms, chlorophytes and, especially, euglenophytes. Increases in chloro- 

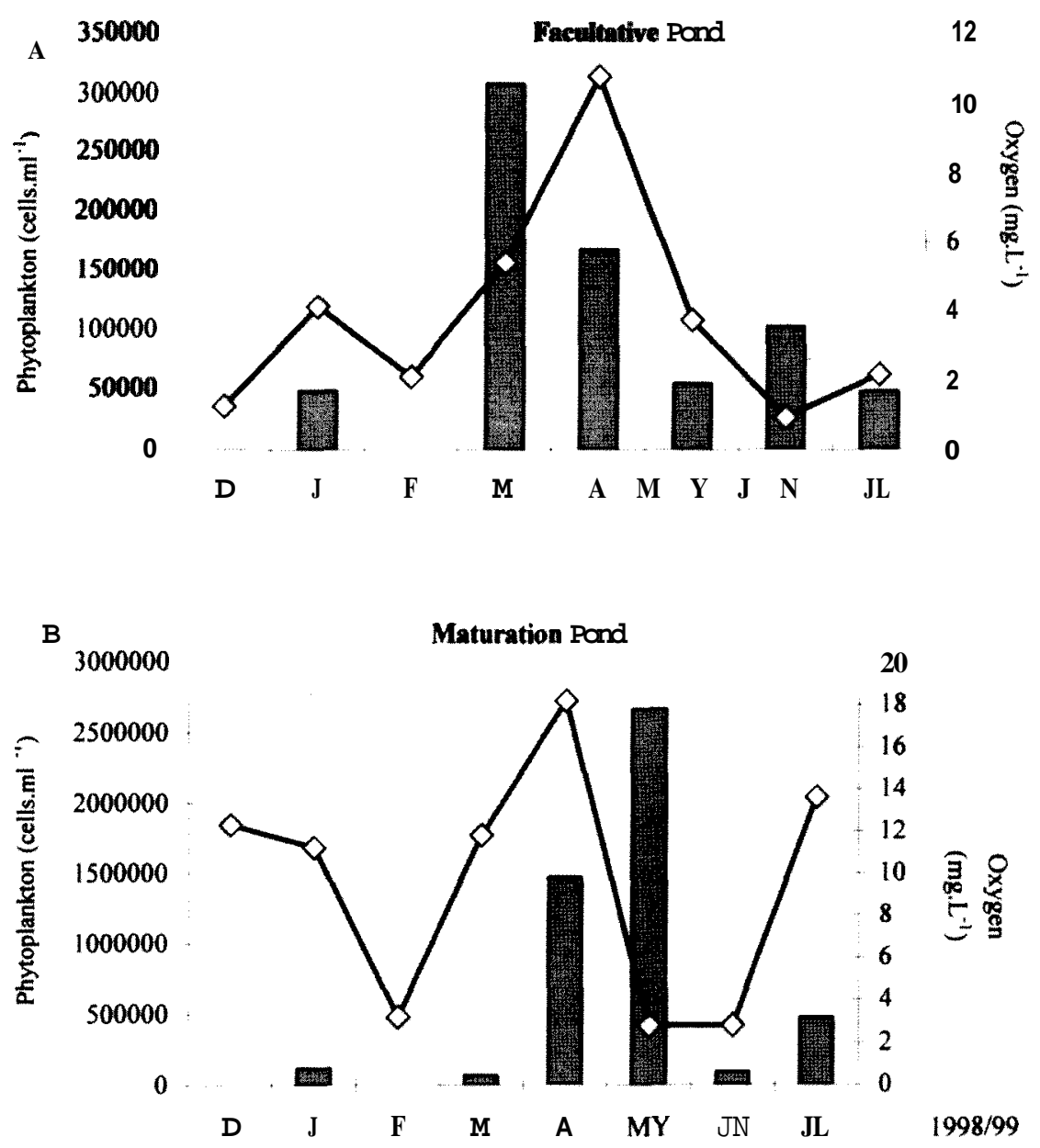

Total phytoplankton abundance $\sim$ Dissolved oxygen

Figure 4. Total phytoplankton dynamics and dissolved oxygen concentration changes in $\mathbf{A}$, the facultative pond and $\mathbf{B}$, in the maturation pond, at the outlet. Dinámica del fitoplanctony de los cumbios en la concentración de oxigeno en $A$, la laguna facultativay $B$, en la laguna de maduración a la salida.

phyll $a$ concentration in the water and $\mathrm{pH}$ were related to euglenophyte density, whereas oxygen concentration changes were related to changes in density of both diatoms and euglenophytes.

\section{Maturation pond}

In the maturation pond, Planktothrix mougeotii (April and May), Microcystis aeruginosa and
Pseudanabaena mucicola (July) were the dominant algal species. These results are similar to those observed during cyanobacteria blooms in fi-eshwaters ecosystems (Vasconcelos, 1994), but contrast with those of Oliveira (1995), who reported dominance of chlorophytes in wastewater stabilization ponds. Microcystis aeruginosa is one of the most common species in freshwaters ecosystems (Vasconcelos, 1994). However, it is not common in WWTP ponds. Other cyanobacterial species 


\section{Maturation Pond}
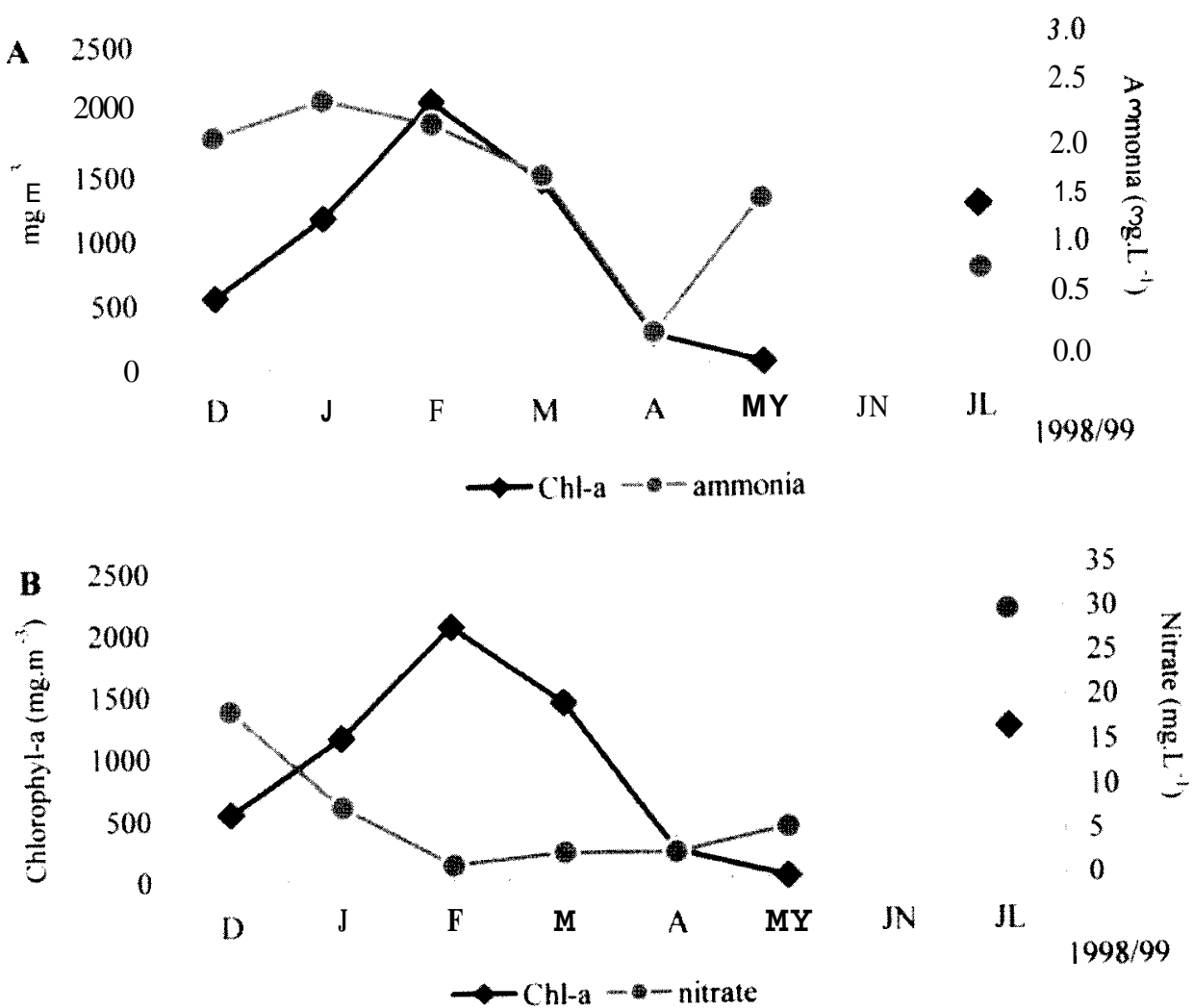

1998/99

C 2500
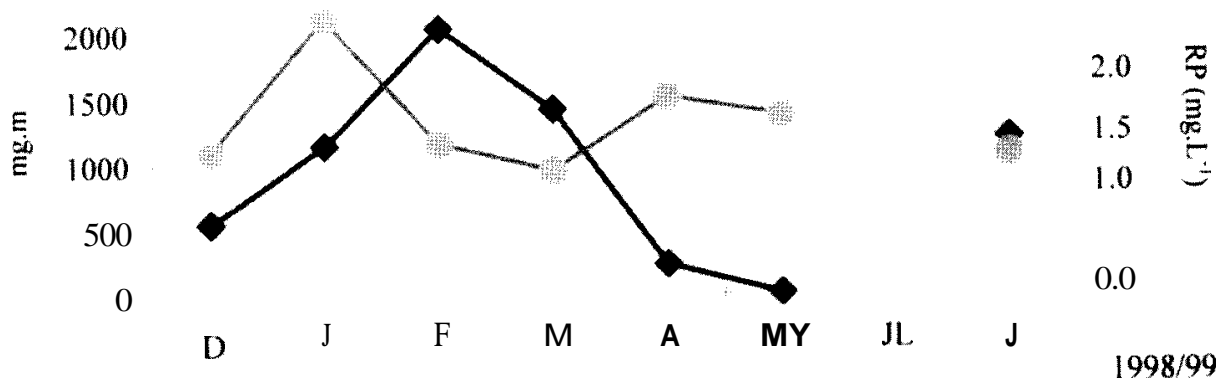

$\sim \mathrm{Chl}-\mathrm{a}-:$ :-Solublereactive phosphorus

Figure 5. Changes in chlorophyll a concentrations $(\mathrm{mg} \mathrm{m}-3)$ in the maturation pond at the outlet versus A, dissolved ammonia concentrations (mg 1-1); B, dissolved nitrate concentrations (mg 1-1) and C, soluble reactive phosphorus concentrations (mg 1-1). Cambios en las concentraciones de clorofila a ( $\mathrm{mg} \mathrm{m}$-3) en el estanque de maduracidn a la salida frente A, las concentraciones de amonio (mg $l-1) ; B$, concentraciones de nitrato ( $m g l-1)$ y C, concentracion de fósforo reactivo soluble ( $m g l-1$ ) 
common in WWTP are Synechoccocus and Synechocystis (Oudra, 1990).

The lowest chlorophyll $a$ concentration was registered in April and May, when cyanobacteria represented $95 \%$ of total phytoplankton density. Thus, the density peak observed in May was mainly the result of a cyanobacterial bloom. Chlorophyll $a$ concentrations in July were high, with a predominance of cyanobacteria, and small amounts of chlorophytes. This could be explained by the varying chlorophyll $a$ content in different algal groups. Chlorophyll $a$ content in cyanobacteria is less than in chlorophytes and euglenophytes (Reynolds, 1984). Also, chlorophyll $a$ content is less in Planktothrix mougeotii than in Microcystis aeruginosa and Pseudanabaena mucicola. Chlorophyll a concentration reached $2042.6 \mathrm{mg} \mathrm{m}^{-3}$ in February. Dissolved oxygen concentrations ranged between 2.8 and $18.2 \mathrm{mg} \mathrm{l}^{-1}$ (Fig. 3B \& 4B).

Increases in chlorophyll $a$ content were correlated to chlorophyte and diatom cell abundance, whereas increases in oxygen concentrations were correlated to density of euglenophytes. Oxygen concentrations and $\mathrm{pH}$ were generally high in WSP due to high photosynthetic activity of phytoplankton. Euglenophytes showed a modest positive correlation to both oxygen concentration and $\mathrm{pH}$, whereas cyanobacteria were found regardless of oxygen concentrations and were strongly correlated with $\mathrm{pH}$. This suggests that Euglenophytes and Cyanobacteria were better adapted to the environment represented by the maturation pond than diatoms and chlorophytes were.

\section{Toxin analyses and quantification}

Negative results for cyanobacterial toxicity were obtained during the Planktothrix mougeotii bloom, using the mouse bioassay. However, ELISA assays specific for hepatotoxic microcystins revealed the presence of these toxins. (Vasconcelos \& Pereira, 2001). The maximum value recorded was of $56.0 \mu \mathrm{g}$ MCYST-LR equiv $\mathrm{I}^{-1}$ in the maturation pond (samples taken from its banks) in July.
Chlorophyll $a$ concentrations showed a marked tendency to follow nutrient concentrations changes, especially at the time of the largest algal bloom, recorded in February. Nitrate, nitrite and soluble reactive phosphorus concentrations registered a strong decrease during this bloom. The decrease in ammonia, however, only began at the end of the algal peak (Fig.5).

Nutrients in the water apparently accumulated before the algal bloom (end of winter-beginning of spring; air temperature was $11^{\circ} \mathrm{C}$ ). An increase in $\mathrm{pH}$ and in dissolved oxygen concentration followed, during or immediately after the algal blooms. These seasonal algal blooms (at least three during the whole year) are typical in lagoons (Surampalli et al., 1995).

Large cyanobacteria densities were measured at the banks of the maturation pond and in the effluent leaving the pond to be discharged into the receiving river Lambo. The Esmoriz wastewater treatment plant may be considered as an optimal habitat for the development of cyanobacteria, and consequently as a potential source of toxins produced by the cyanobacteria and released into the environment.

\section{REFERENCES}

CANIZARES-VILLANUEVA, R. O., A. I. RAMOS M, O.MONROY, M. DE LA TORRE, C. GOMEZLOJERO \& L. TRAVIESSO. 1994. Phormidium treatment of anaerobically treated swine wastewater. Wat.Res., 28: 1891-1895

CURTIS, T. P. \& D. D. MARA. 1994. The effect of sunlight on mechanisms for die-off of faecal co liform bacteria in waste stabilization ponds. In: Research Monograph $\mathrm{n}^{\mathrm{o}}$ I. (University of Leeds, Dept. of Civil Engineering) 94pp

GOLTERMAN, H. L., R. S. CLYMO. \& M.A.M. OHNSTAD. 1978. Methods for the physical and chemical analysis of freshwater $\left(3^{\text {rd }} E d\right.$.). IBP Handbook $n^{\circ}$ 8. (Blackwell Scientific Publications). 213 pp. Oxford, Edinburgh.

KOROLEFF, F. 1970. Direct determination of ammonia in natural waters as indolphenol blue. Information on techniques and methods for seawater analysis Cons. Int Explor. Mer. Service. Hydrographique. Interlaboratory Report, 3: 19-22. 
LUND, J. W. G., KIPLING, C. \& E. D. LECREN. 1958. The inverted microscope methods of estimating algal numbers and the statistical basis of estimation by counting. Hydrobiologia, 11: 143170.

MENDES, B. S., NASCIMENTO, M. J., PEREIRA, M. I., BAYLEY, G., LAPA, N., MORAIS, J. \& J. S. OLIVEIRA. 1995. Efficiency of removal in stabilization ponds. Influence of climate. Wat. Sci. Technol., $31: 2$ 19-229.

NP 4327. 1996. Qualidade da agua. Doseamento de clorofila a e dos feopigmentos por espectofotometria molecular. Método de extraç̧ão com acetona. Norma portuguesa. IPQ.

NURDOGAN, Y. \& W. J. OSWALD, 1995. Enhanced nutrient removal in high-rate ponds. Wat. Sci. Technol., $31:$ 33-34.

OLIVEIRA, T. F. S. 1995. A lagunagem em portugal. conceitos busicos e aplicações pruticas. Ed. Universitárias Lusofonas, Lda.,516 pp

OUDRA, B. 1990. Bassins de stabilization anaérobiefacultatifpour le traitement des eaux usées à Marrakesh: Dynamigue duphytoplankton (microplankton et picoplankton) et évaluation de la biomasse primaire. These de $3^{\text {eme }}$ cycle. Univ, Cady Ayyad. Fac. Sci. Marrakesh, 144 pp

REYNOLDS, C. 1984. THE ECOLOGY OF FRESHWATER PHYTOPLANKTON. Freshwater Biol. Ass., Cambrigde Univ. Press. Cambrigde.
RODRIGUES, A. M. F. \& F. J. P. SANTANA. 1993. Tratamento de aguas residuais por microalgas. Bol. UCA. Uni.Algarve, UCTRA, 1: 82-599.

SILVA, M.S.G. 1998. Biofilme bacterio-algal associado a sistemas de lagunagem. Eficiência no tratamento de efluentes domesticos. Dissertação de Mestrado de Engenharia do Ambiente. Faculdade de Engenharia do Porto, 112 pp.

STRICKLAND J. D. H. \& T. R. PARSONS. 1972. A Practical Handbook of Seawater Analysis. Fish. Res. Bd. Can. Bulletin 167 ( $2^{\text {nd }}$ Ed.) 311 pp.

SURAMPALLI, R. Y., S. K. BANERJI, C. J. PYCHE, C.J. \& E.R. LOPEZ. 1995. Phosphorus removal in ponds. Wat Sci. Technol., 31: 331-339.

TROUSSELLIER, M., P. LEGENDRE. \& B. BALEUX. 1986. Modelling of the evolution of bacterial densities in a eutrophic e ecosystem (sewage lagoons). Microb. Ecol., 12: 355-379.

VASCONCELOS, V. M. 1994. Toxic cyanobacteria (blue-green algae) in Portuguese freshwaters. Arch. Hydrobiol. 130: 49-451.

VASCONCELOS, V. M. \& F. O ARAÚJO.1994. Cianobactérias - um risco para o umbiente e para a Saude Humana. Instituto da Agua, Ministerio da Saude, Ministério do Ambiente e Recursos Humanos e Direcção-Geral da Saude, 24 pp.

VASCONCELOS, V. M. \& E. M PEREIRA. 2001. Cyanobacteria diversity and toxicity in a Wastewater Treatment Plant (Portugal). Water Research, 35 (5): 1354-1357. 